\title{
The Effects of Green Tea on the Body Weight and Histoarchitecture of the Testis of Adult Male Sprague dawley Rats
}

\author{
Alabi AS ${ }^{1}$, Arokoyo R' ${ }^{1}$, Oyewopo AO ${ }^{1}$, Lewu FS ${ }^{1}$, Kareem SB ${ }^{1}$, Aigbogun EO ${ }^{2, *}$
}

Alabi AS ${ }^{1}$, Arokoyo R', Oyewopo $\mathrm{AO}^{1}$, Lewu FS 1 , Kareem SB ${ }^{1}$, Aigbogun $\mathrm{EO}^{2, *}$

'Department of Anatomy, College of Health Sciences, University of Ilorin, Kwara State, NIGERIA.

${ }^{2}$ Department of Anatomy, Faculty of Basic Medical Sciences, College of Health Sciences, University of Port-Harcourt, Rivers State, NIGERIA.

\section{Correspondence}

\section{Dr. Aigbogun Eric}

Department of Anatomy, Faculty of Basic Medical Sciences, College of Health Sciences, University of Port Harcourt, Rivers State, NIGERIA.

Phone: +2347031135557

Email: eric_aigbogun@uniport.edu.ng

History

- Submission Date: 14-09-2018

- Review completed: 19-11-2018;

- Accepted Date: 10-12-2018.

DOI : 10.5530/ijcep.2018.5.3.8

Copyright

(C) 2018 Phcog.Net. This is an openaccess article distributed under the terms of the Creative Commons Attribution 4.0 International license.

\begin{abstract}
Background and Aim: Green tea is an aromatic beverage derived from the cured leaves of Camellia sinensis. It is a potent herb which serves various therapeutic purposes. This study was carried out to determine the effect of the administration of various concentration of green tea extract (GTE) on the histoarchitecture of the testis of Sprague dawley adult male rat. Methods: 20 animals were divided into four groups, comprising of 5 animals each. The control group was given distilled water while the treated groups were given $2 \mathrm{ml} / \mathrm{kg}, 4 \mathrm{ml} / \mathrm{kg}$ and $6 \mathrm{ml} / \mathrm{kg}$ of aqueous extract of green tea respectively for 26 days. At the end of the administration on the 27th day, in accordance with IACUC regulation, the animals were euthanized following the administration of AGTE after which they were dissected and the testes were excised for tissue processing. Results: There was a progressive decrease in weight of the treated animals corresponding to the increase in the concentration of green tea. The histological analysis showed that the GTE at $2 \mathrm{ml} / \mathrm{kg}$ did not disrupt the histoarchitecture of the testicular tissue; however, there was mild to moderate degeneration at $4 \mathrm{ml} / \mathrm{kg}$ and $6 \mathrm{ml} / \mathrm{kg}$ respectively and this histoarchitectural distortions of the testis by of GTE may take a direct or indirect path; thus, may induce testicular dysfunction. The Feulgen stain intensity was more in the control and group 1, when compared to group 2 and 3 , which is a pointer to DNA material loss in testicular tissues at higher doses. Conclusion: Lower dose of GTE may seem beneficial; however higher doses pose more harm in a short period, when compared to the benefit of the lower dose on the body and testicular tissue. However, there is the need for further investigation on the role and mechanism of action of GTE on testicular cellular and tissue dysfunction and consequence on reproduction.
\end{abstract}

Key words: Green tea (Camellia sinensis), Body weight, Histoarchitecture, Sprague dawley rats, Testis.

\section{INTRODUCTION}

Plants are globally used as therapeutic agents since ancient time. ${ }^{[1]}$ Several plants are reported to enhance the reproductive process and some are known to hamper such functions. Green tea extract (GTE) has been used in traditional Chinese medicine for centuries to treat and prevent chronic. ${ }^{[2,3]}$ Green tea is made from the steamed leaves and shrubs of camellia sinensis that have undergone fermented (oxidized) processing. ${ }^{[2]}$ Many natural substances have been identified in green tea; ${ }^{[4]}$ the theanine and catechins components have neuroprotective functions, ${ }^{[5,6]}$ and the catechins inhibit tumor cell proliferation and promote destruction of leukemia cells $s^{[7,8]}$ and breast cancer cells. ${ }^{[9]}$ Studies have shown that green tea decreases the risk of ovarian cancer ${ }^{[10]}$ and reduces the proliferation of cervical, ${ }^{[11]}$ prostate $^{[12]}$ and pancreatic carcinoma cells. ${ }^{[13]}$

Green tea was shown to be an aromatase inhibitor in rat; ${ }^{[14]}$ a causative factor for an increase in testosterone level. ${ }^{[14,15]}$ It has been reported that there was a decrease in plasma testosterone level by green tea epigallocatechin-gallate (EGCG). Goitrogenic/anti- thyroidal effect of GTE, in relatively high doses has been reported in both in-vivo and in-vitro studies, ${ }^{[16]}$ as well as the role of thyroid hormone on the growth and normal functioning of the male gonads. ${ }^{[16,17]}$ Green tea is marketed commercially in Nigeria as tea bags, in various brand names. Green tea can taste sweet, bitter or astringent depending on the temperature of the water $60^{\circ} \mathrm{C}$ water for sweet $80^{\circ} \mathrm{C}$ for astringent and $100^{\circ} \mathrm{C}$ of water for bitter tea respectively.

\section{MATERIALS AND METHODS}

Twenty 58 - 62 days old male albino Sprague dawley rats (Rattus Norvegicus), weighing about $90 \mathrm{~g}-200 \mathrm{~g}$ were used in this study. Animals were maintained in line with the national guidelines and protocol of the Institutional Animal Care and Use Committee (IACUC) $\cdot{ }^{[18]}$ Animals were housed in clean net cages with adequate space to enhance free movement. The environmental condition was kept relatively constant with good lighting and temperature in the animal house of the Anatomy Department of the University
Cite this article: Alabi AS, Arokoyo R, Oyewopo AO, Lewu FS, Kareem SB, Aigbogun EO. The Effects of Green Tea on the Body Weight and Histoarchitecture of the Testis of Adult Male Sprague dawley Rats. Int J Clin Exp Physiol. 2018;5(3):141-4. 
of Ilorin and this was maintained throughout the course of the experiment and water given ad lib.

The green tea (sachet) was acquired from a tea store in Ilorin. The tea is the commercial version of the standard preparation. ${ }^{[19]}$ Each bag of green tea has a net weight of $2 \mathrm{~g}$ each, the aqueous extract was prepared in three different concentration with $100 \mathrm{ml}$ of boiling distilled water as the solvent; low concentration ( $2 \mathrm{~g}$ of green tea), moderate concentration ( $4 \mathrm{~g}$ of green tea), high concentration ( $6 \mathrm{~g}$ of green tea). The aqueous extract was obtained by boiling the distilled water up to $100^{\circ} \mathrm{C}$, the boiling water was then poured into a cup which contained the green tea bag and allowed to stand for $4 \mathrm{mins}$. This procedure was repeated for each of the concentrations differently.

\section{Grouping of Rats}

The animals were divided into 4 equal groups of 5 rats per group according to their average body weight. Groups 1-3 were the treated groups and group 4 was the control group. The administration lasted for 26 days and was carried out in the early hours of the morning before daily feeding. Group 1 was administered $2 \mathrm{ml} / \mathrm{kg}$ the low concentration of aqueous green tea extract (AGTE), group 2 was given $4 \mathrm{ml} / \mathrm{kg}$ of the concentration AGTE, group 3 was given $6 \mathrm{ml} / \mathrm{kg}$ of the high concentration of the AGTE and group 4 (control) was given $2 \mathrm{ml} / \mathrm{kg}$ of distilled water. The extract was administered orally using the oropharyngeal cannula and a syringe (2.0ml).

In accordance to the regulation by IACUC, animals were euthanized on the 27th day following administration of the AGTE after which they were dissected and the testes were excised for histological examination.

\section{Statistical analysis of data}

ANOVA using Microsoft Excel (2016) was used to compare the mean body weight of the experimental groups and the control. 95\% confidence level was set and P-value $<0.05$ was considered significant.

\section{RESULTS}

Group 2 and 3 animals showed noticeable increase in food and water consumption after the administration of $4 \mathrm{ml} / \mathrm{kg}$ and $6 \mathrm{ml} / \mathrm{kg}$ of GTE. Group 1 showed fluctuations in food consumption, while the consumption in the control was normal, hence the steady increase in weight.

There was a progressive and significant increase in weight loss as the concentration of green tea increased (that is; the Dif. for $2 \mathrm{ml} / \mathrm{kg}[5.8 \%$ loss] and $6 \mathrm{ml} / \mathrm{kg}$ [12.4\%] significant at $P<0.05)$. Group 1 had minor weight loss of about $1.4 \%$ of the weight before administration while the control group however maintained a steady increase in weight gain (F.W $=14.8 \%$ of weight before administration) (Figure 1).

Photomicrograph of the control group showed a well-preserved morphology and the cross-section of the seminiferous tubules clearly showed normal testicular tissue with the spermatogenic cells and non-spermatogenic cells population. Also, a normal stroma consisting of interstitial Leydig cells was observed. There was organisation of cells in the control groups compared with some of the experimental groups. The tubules were regular and were densely populated with spermatogonium (Figure 2). Group 1 showed a similar characteristic to the control group. The photomicrograph of groups 2 and 3 showed mildly degenerated testicular tissue. The cell population was not as organized as the control group and group 1. Group 2, examination of the seminiferous tubules shows a distinct difference from that of the control group because the cells were closely adhered to each other and there was a mild loss of the stroma of the interstitial cells, mild reduction of the spermatogenic cells, sperm cells and Sertoli cells. The Leydig cells were visible but sparsely populated. Group 3 that received $6 \mathrm{ml} / \mathrm{kg}$ of GTE which twice and thrice the concentration received by group 1 and 2 respectively, showed inflammatory reactions and moderately distorted testicular structure. There were few populations of spermatogenic cells and the seminiferous tubule was not as organized as the control group. The seminiferous tubule was irregular and there was a great decrease in the number of sperm cells in the lumen of the tubules (Figure 2)

The dividing cells of the control and group 1 showed more staining intensity (Dark-reddish or Magenta). Compared to group 2 and 3 they are more Feulgen positive (Figure 3).

\section{DISCUSSION}

Previous researches showed that the harmful effects of green tea consumption are not as much compared to the beneficial and the therapeutic effects. Administration of green tea extract orally, at relatively low, moderate and high concentrations daily for 26 days, reduced the net weight of the treated animals when compared to the control animals, although significant reduction was observed in group 2 and 3 but not group 1. This agrees with previous studies by Kao et al. ${ }^{[15]}$ WesterterpPlantenga, ${ }^{[20]}$ and Lu et al. ${ }^{[21]}$ as they reported dose-dependent decrease in the net weight gained; prior to the administration of Green tea extract (GTE). Studies have linked the actions of polyphenols to increase loss of body weight following consumption of GTE, which was reported to be due to the inhibition of catechol-o-methyl tranferase (COMT) enzymes by catechins (EGCG) in the tea ${ }^{[15,20,22]}$ and modulation of obesity related genes. ${ }^{[21]}$ Additionally, thermogenesis and fat oxidation are stimulated by norepinephrine, and COMT degrades norepinephrine. ${ }^{[22,23]}$ Thus, the inhibition of COMT by EGCG decreases body weight.

The cross-section of the seminiferous tubules of group 1 had similar characteristic as that of the control group, as against groups 2 and 3 , which showed mildly degenerated testicular tissue. This finding suggests that moderate consumption of green tea at not more than $2 \mathrm{ml} / \mathrm{kg}$ over a period of time may not affect the reproductive characteristics of the male gonads, while high consumption above $4 \mathrm{~m} / \mathrm{kg}$ could induce degenerative changes. Negative effect on higher consumption has also been as reported by Chandra et al. ${ }^{[24]}$ It is still suspected that the histoarchitectural distortions of the testis by of GTE may take a direct or indirect path; thus, may induce testicular dysfunction; ${ }^{[25]}$ however, these assumptions require further investigations.

The DNA Feulgen reaction was well demonstrated in the spermatogenic cells by the dark-reddish - coloured stain which indicates Feulgen positivity. The intensity of the stain was more in the control and group 1. The intensity of the stain was however lower in group 2 and 3 compared to the control group and group 1 which received the lower concentration of green tea. The intensity of the stain represents positivity of the Feulgen reaction; hence the presence of more DNA. ${ }^{[24]}$ The mechanism of GTE

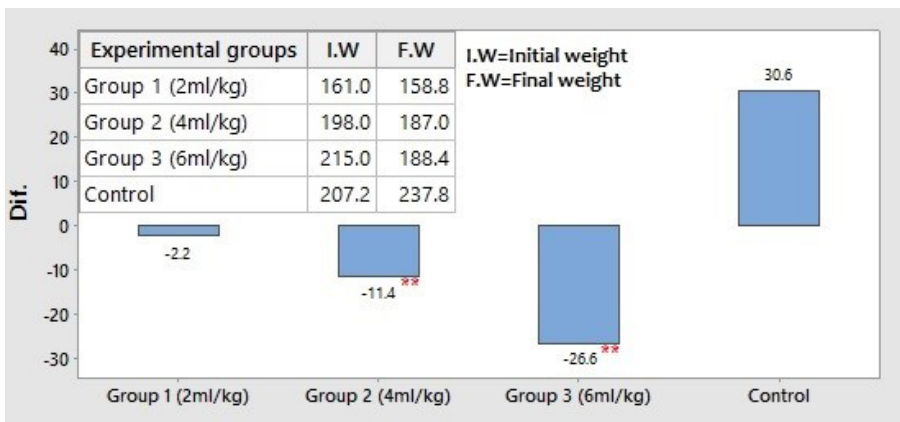

Figure 1: Weight differences [Dif.] for the groups, before [I.W] and after [F.W] administration (**Dif. significant at $\mathrm{P}<0.01$ ) 

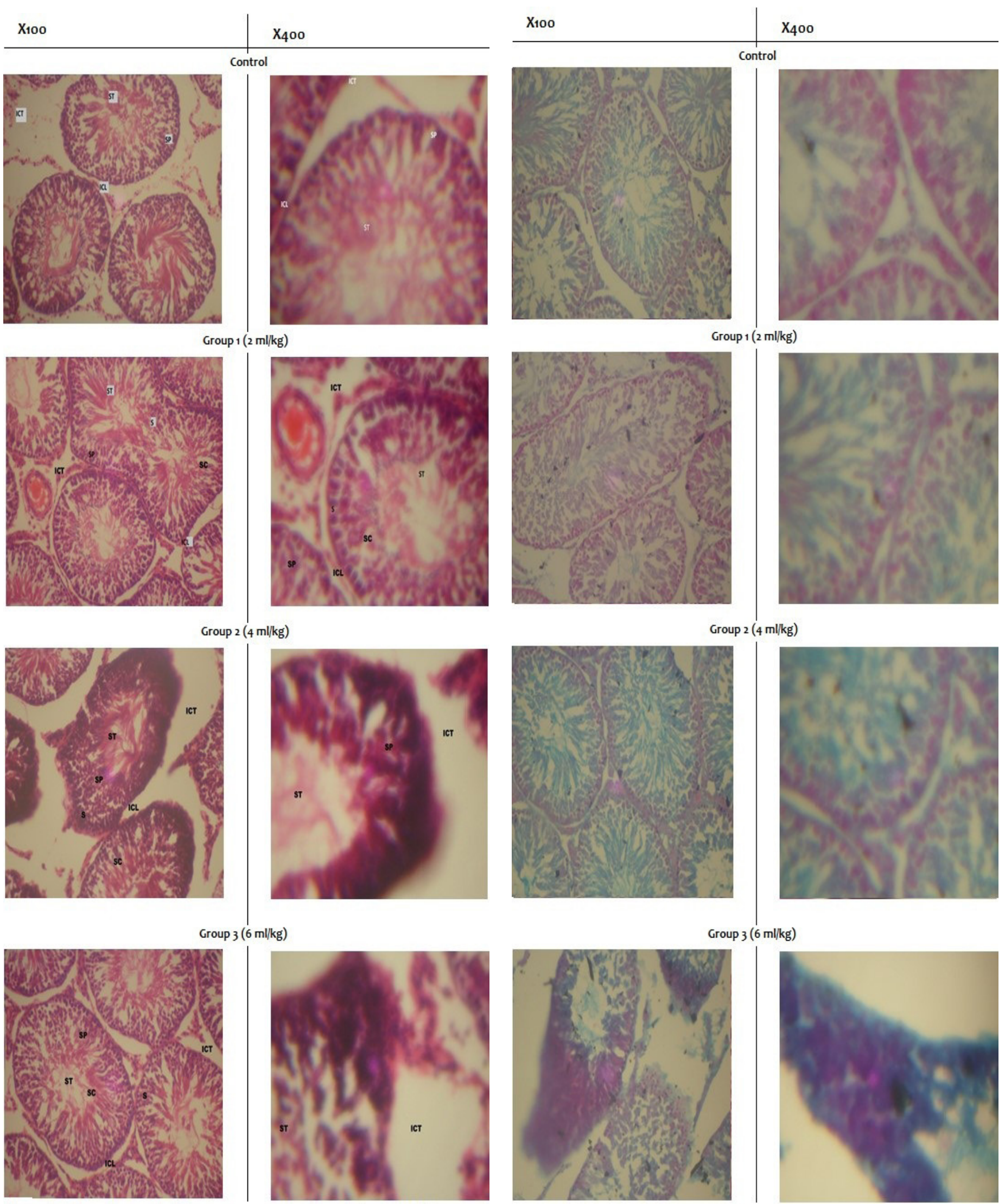

Figure 2: Photomicrograph of the transverse section through the testis of the control and experimental groups using H\&E (MG X100 AND 400). ICLinterstitial cell of leydig, ICT- Interstitial connective tissues, ST-Spermatids, SP-Spermatogonia and SC- Sertolic cells.
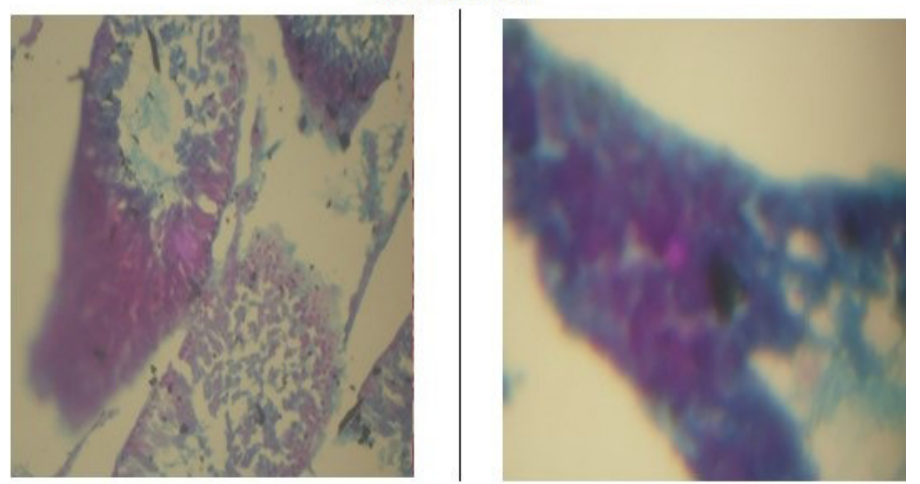

Figure 3: Photomicrograph of the transverse section through the testis of the control and experimental groups using Feulgen (MG X100 AND 400). 
induced loss of DNA materials in testicular tissues that hampered a clear positive Feulgen reaction in group 2 and 3 is an indication for further investigation, but current findings of the effect of GTE at higher dose suggests negative outcomes.

\section{CONCLUSION}

The observations in this study leads to the conclusion that lower dose of GTE may seem beneficial; however higher doses pose more harm in a short period, when compared to the benefit of the lower dose on the body and testicular tissue. However, further investigation on the role and mechanism of action of GTE on testicular cellular and tissue dysfunction and consequence on reproduction.

\section{ACKNOWLEDGEMENT}

The authors wish to thank the Heads of Department of the University of Ilorin and the University of Port Harcourt for their role in ensuring the collaboration was a success. The authors extend their warm gratitude to the laboratory technicians for their conscious and voluntary contributions during the experimental period.

\section{CONFLICT OF INTEREST}

The authors declare no conflict of interest.

\section{ABBREVIATIONS}

AGTE: Aqueous Green Tea Extract; COMT: Catechol-O-Methyl Tranferase ; EGCG: Epigallocatechin-gallate; GTE: Green Tea Extract; IACUC: Institutional Animal Care and Use Committee.

\section{SUMMARY}

This study observed the effect on Green Tea Extract (GTE) on the body weight and testicular histoachitecture of Sprague Dawley adult male rat. GTE was administered at different doses to the animals, which were group into four (4) depending on their weight and dosage. The animal weights were observed and document throughout the experimental period. At the end of the administration, histological tissues were excised in line with international best practices. The results provided the stands of the researchers to conclude that, although lower dose of GTE seemed beneficial, higher doses produce low to moderate negative consequences

\section{REFERENCES}

1. Abdel-Rahman A, Anyangwe N, Carlacci L, Casper S, Danam RP, Enongene E, et al. The safety and regulation of natural products used as foods and food ingredients. Toxicol Sci. 2011;123(2):333-48.

2. Liao S. The medicinal action of androgens and green tea epigallo-catechingallate. Hong Kong Med J. 2001;7(4):369-74.

3. Rahayu RP, Prasetyo RA, Purwanto DA, Kresnoadi U, Iskandar RPD, Rubianto M. The immunomodulatory effect of green tea (Camellia sinensis) leaves extract on immunocompromised Wistar rats infected by Candida albicans. Vet World. 2018;11(6):765-70
4. Tanaka T, Matsuo Y, Kouno I. Biochemical and physicochemical characteristics of green tea polyphenols. In: Green Tea Polyphenols, Nutraceuticals of Modern Life. Boca Raton: CRC Press. 2013;19-29.

5. Yokogoshi $\mathrm{H}$, Kobayoshi M. Hypertensive effects of gamma gluthamylmethylamide in spontaneous hypertensive rats. Life Sci. 1998;62(12):1065-8.

6. Kakuda T. Neuroprotective effects of the green tea components theanine and catechins. Biol Pharm Bull. 2002;25(12):1513-8.

7. Thakur VS, Gupta K, Gupta S. Green tea polyphenols causes cell cycle arrest and apoptosis in prostate cancer cells by suppressing class I histone deacetylases. Carcinogenesis. 2012;33(2):377-84.

8. Wu D, Wang J, Pae M, Meydani SN. Green tea EGCG, T cells, and T cell-mediated autoimmune diseases. Mol Aspects Med. 2012;33(1):107-18.

9. Vergote D, Cren-Olivé C, Chopin V, Toillon RA, Rolando C, Hondermarck $\mathrm{H}$, et al. (-)-Epigallocatechin (EGC) of green tea induces apoptosis of human breast cancer cells but not of their normal counterparts. Breast Cancer Res Treat. 2002;76(3):195-201.

10. Zhan X, Wang J, Pan S, Lu C. Tea consumption and the risk of ovarian cancer: A meta-analysis of epidemiological studies. Oncotarget. 2017;8(23):37796-806.

11. Ahn WS, Huh SW, Bae SM, Lee IP, Lee JM, Namkang SE, et al. A major constituent of green tea, EGCG inhibits growth of a human cervical cancer cell lines, caski cells through apoptosis, G (1) onset and regulation of gene expression. DNA Cell Biol. 2003;22(3):217-24.

12. Fujiki H, Watanabe T, Sueoka E, Rawangkan A, Suganuma M. Cancer Prevention with Green Tea and Its Principal Constituent, EGCG: from Early Investigations to Current Focus on Human Cancer Stem Cells. Mol Cells. 2018;41(2):73-82.

13. Hussain T, Gupta S, Adhami VM, Mukhtar H. Green tea constituent epigallocatechin-3-gallate selectively inhibits COX-2 without affecting COX-1 expression in human prostate carcinoma cells. Int J Cancer. 2005;113(4):660-9.

14. Satoh K, Sakamoto Y, Ogata A, Nagai F, Mikuriya H, Numazawa M, et al. Inhibition of aromatase activity by green tea extract catechins and their endocrinological effects of oral administration in rats. Food Chem Toxicol. 2002;40(7):925-33.

15. Kao YH, Hiipakka RA, Liao S. Modulation of endocrine of tea and food intake by green tea ECGC. Endocrinol. 2000;141(3):980-7.

16. Chandra AK, De N. Goitrogenic and Antithyroid Potential of Green Tea of Indian Origin. Bangladesh Soc Physiol. 2014;9(2):105-16.

17. Longcope $\mathrm{C}$. The male and female reproductive systems in hypothyroidism. The thyroid: A fundamental and clinical text. $8^{\text {th }}$ Ed. Philadelphia. PA: LippincottRaven. 2000;824-7.

18. National Institutes of Health Office of Laboratory Animal Welfare (NIH). Public Health Service policy on the humane care and use of laboratory animals. Bethesda, MD: NIH. 2002 [cited 2018 Aug 1].

19. Safdar N, Sarfaraz A, Kazmi Z, Yasmin Z. Ten different brewing methods of green tea: comparative antioxidant study. JAAB. 2016;4(03):033-40.

20. Lu C, Zhu W, Shen CL, Gao W. Green tea polyphenols reduce body weight in rats by modulating obesity-related genes. PLoS ONE. 2012;7(6):e38332.

21. Westerterp-Plantenga MS. Green tea catechins, caffeine and body-weight regulation. Physiol Behav. 2010;100(1):42-6.

22. Dulloo AG, Duret C, Rohrer D, Girardier L, Mensi N, Fathi M, et al. Efficacy of a green tea extract rich in catechin polyphenols and caffeine in increasing 24-h energy expenditure and fat oxidation in humans. Am J Clin Nutr. 1999;70(6):1040-5.

23. Lamprecht M. Green Tea Catechins and Sport Performance (Chapter 8): Antioxidants in Sport Nutrition. Boca Raton (FL): CRC Press/Taylor and Francis. 2015.

24. Chandra AK, De N. Goitregenic/Antithyroidal potential of green tea extracts in relation to catechins in rats. Food Chem Toxic. 2010;48(8-9):2304-11.

25. Chandra AK, Choudhury SR, De N, Sarkar M. Effect of green tea (Camellia sinensis L.) extract on morphological and functional changes in adult male gonads of albino rats. Indian J Exp Biol. 2011;49(9):689-97.

Cite this article: Alabi AS, Arokoyo R, Oyewopo AO, Lewu FS, Kareem SB, Aigbogun EO. The Effects of Green Tea on the Body Weight and Histoarchitecture of the Testis of Adult Male Sprague dawley Rats. Int J Clin Exp Physiol. 2018;5(3):141-4. 